\title{
An Experimental and Comparative study about the engine Emissions of conventional Diesel Engine and Dual Fuel engine
}

\author{
Ghazanfar Mehdi ${ }^{1,2}$, Syed Asad Ali Zaidi ${ }^{1,3}$, M.Mustafa Azeem ${ }^{4}$, Salman \\ $\mathrm{Abdu}^{1}$
}

\begin{abstract}
:
Because of the high thermal effectiveness, consistency, flexibility and economical cost diesel engines are extensively used all around the world. Diesel engine emissions are producing serious environmental pollution which consists of oxides of nitrogen $\left(\mathrm{NO}_{\mathrm{X}}\right)$, carbon monoxide (CO) and particulate matter (PM). So it's necessary to find the alternate solution to control diesel emissions. Natural gas is a highly attractive due to its clean burning, low cost, and wide availability. In this experimental work, single cylinder (8.6 Hp LA186F) four-stroke conventional diesel engine was studied. Natural gas is the major gaseous fuel used in dual fuel method which is up to $80 \%$ while diesel is used as a pilot fuel for the source of ignition up to $20 \%$. In comparison with the conventional diesel method, it was observed that the dual fuel method significantly reduces the $\mathrm{NO}_{\mathrm{x}}$ maximum up to $72.5 \%$, carbon dioxide $\left(\mathrm{CO}_{2}\right) 34.5 \%$ and CO 59.8\%. However, Hydrocarbon (HC) increased $66.76 \%$ in contrast with normal diesel combustion. During dual fuel mode, the emissions of $\mathrm{HC}$ and $\mathrm{NO}_{\mathrm{X}}$ shows the inverse relation.
\end{abstract}

\section{Keywords: Diesel; Dual fuel; Emission; Natural gas; Combustion.}

\section{Introduction}

Diesel engines are extensively used in the public transportation because of their higher stability and thermal effectiveness. Meanwhile, greenhouse gases are produced by transportation sector is about $30 \%$ of the world which leads to global warming [1]. Therefore, diesel engine is more responsible for the serious atmospheric hazards [2]. $\mathrm{NO}_{\mathrm{X}}$ and $\mathrm{PM}$ are the main harmful components of diesel engine. $\mathrm{NO}_{\mathrm{X}}$ emission produces photochemical smog which is a major source of acid rain [3]. It has been proved by numerous studies that these gases can be enormously harmful to the environment, especially living beings as health hazard [4]. Hence, emission regulations become stricter to reduce this environmental pollution. At the same time, energy consumption is growing rapidly and the fossil fuels are dwindling. In this regard, use of alternative fuels is necessary to meet the requirement of energy consumption and standard emission regulations. In public transport, natural gas is more environmental friendly among the various alternative fuels. Because of its clean burning, widely spread distribution stations, and lower cost [5].

${ }^{1}$ College of Power and Energy Engineering, Harbin Engineering University, Harbin, PR China.

${ }^{2}$ Faculty of Engineering Science and Technology, Indus University, Karachi, Pakistan

${ }^{3}$ Department of Engineering Sciences, PN Engineering College, National University of Sciences and Technology, Karachi, Pakistan.

${ }^{4}$ College of Nuclear Science \& Technology, Harbin Engineering University, Harbin 150001, PR China.

Corresponding Email: ghazanfarmehdi22@gmail.com 
Ghazanfar Mehdi (et al.), An Experimental and Comparitive study about the engine emissions of conventional diesel engine and dual fuel engine

(pp. 81-87)

\subsection{Natural gas used as a substitute fuel}

In comparison by means of other alternative methods, the more attractive source of energy is natural gas used in the internal combustion engines[6]. Natural gas has desirable advantages including low emission of greenhouse gases and reduction of capital costs. Currently, due to environmental issues and energy shortage problems, governments of the worldwide are looking to the natural gas as a substitute fuel for conventional diesel engine [7].

\subsection{Physiochemical properties of natural gas} Methane is the major part of natural gas which is near about $90 \%$.

TABLE I. Typical components of natural gas [8].

\begin{tabular}{|l|l|l|}
\hline Content & $\begin{array}{l}\text { Typical } \\
\text { investigation } \\
\text { (Vol. \%) }\end{array}$ & $\begin{array}{l}\text { Range } \\
\text { (Vol. \%) }\end{array}$ \\
\hline Methane & 94.9 & $87.0-96.0$ \\
\hline Ethane & 2.5 & $1.8-5.1$ \\
\hline Propane & 0.2 & $0.1-1.5$ \\
\hline Isobutane & 0.03 & $0.01-0.3$ \\
\hline n-butane & 0.03 & $0.01-0.03$ \\
\hline Isopentane & 0.01 & Trace to 0.14 \\
\hline n-pentane & 0.01 & Trace to 0.14 \\
\hline Hexane & 0.01 & Trace to 0.06 \\
\hline Nitrogen & 1.6 & $1.3-5.6$ \\
\hline $\begin{array}{l}\text { Carbon } \\
\text { dioxide }\end{array}$ & 0.7 & $0.1-1.0$ \\
\hline Oxygen & 0.02 & $0.01-0.1$ \\
\hline Hydrogen & Trace & Trace to 0.02 \\
\hline
\end{tabular}

But with methane, it also consists of many numbers of gases namely ethane, propane, pentanes, n-butane and lightweight alkanes. Nitrogen, carbon dioxide and traces of water vapors are also the components of natural gas. Natural gas properties vary according to the composition, source of production, and process used.

Table 1 shows the composition of natural gas [8]. Mostly, Natural gas consists of $87-96 \%$ of methane. Due to this reason, natural gas has same physical and chemical characteristics like methane.
Table 2 represents fuel properties of gasoline and diesel in comparison to natural gas [9-10]. In contrast with other fossil fuels, natural gas consists of less carbon per unit energy, therefore for public transport natural gas is environmental attractive as it produces low $\mathrm{CO}_{2}$ emissions per mile. Although, because of the higher auto-ignition temperatures of natural gas it is intricate to used it in diesel engines. However, for spark ignition engines natural gas is very favorable because of anti-knock quality. Further, Natural gas is used in diesel engines without auxiliary modifications.

TABLE II. Physical and chemical characteristics of gasoline, natural gas and diesel [9-10].

\begin{tabular}{|l|l|l|l|}
\hline $\begin{array}{l}\text { Fuel } \\
\text { Properties }\end{array}$ & $\begin{array}{l}\text { Natural } \\
\text { gas }\end{array}$ & Diesel & Gasoline \\
\hline $\begin{array}{l}\text { Low Heating } \\
\text { Value(MJ/kg) }\end{array}$ & 48.6 & 42.5 & 43.5 \\
\hline $\begin{array}{l}\text { Heating value } \\
\text { of } \\
\text { stoichiometric } \\
\text { mixture } \\
\text { (MJ/kg) }\end{array}$ & 2.67 & 2.79 & 2.78 \\
\hline $\begin{array}{l}\text { Cetane } \\
\text { number }\end{array}$ & - & 52.1 & $13-17$ \\
\hline $\begin{array}{l}\text { Octane } \\
\text { number }\end{array}$ & 130 & - & $85-95$ \\
\hline $\begin{array}{l}\text { Auto-ignition } \\
\text { temperature } \\
\left({ }^{\circ} \text { C) }\right.\end{array}$ & 650 & $180-$ & 310 \\
\hline $\begin{array}{l}\text { Stoichiometric } \\
\text { air-fuel ratio } \\
\text { (kg/kg) }\end{array}$ & 17.2 & 14.3 & 14.56 \\
\hline $\begin{array}{l}\text { Carbon } \\
\text { content }(\%)\end{array}$ & 75 & 87 & 85.5 \\
\hline
\end{tabular}

\section{Dual fuel concept}

According to the dual fuel methodology, the intake manifold is used to mix the air stream and natural gas uniformly then it is introduced into the combustion chamber and pilot fuel with high 
Ghazanfar Mehdi (et al.), An Experimental and Comparitive study about the engine emissions of conventional diesel engine and dual fuel engine

cetane number is used for ignition [11-12]. A systematic diagram of dual fuel mode is shown in Fig. 1.

In dual fuel mode, no serious modification is required. It is very easy to put in practice like a conventional diesel engine. However, this technology reduces more than $80 \%$ of diesel fuel [13]. The natural gas is introduced as a major gaseous fuel while diesel is only used for ignition purpose. Hence the performance of dual fuel has been increased.

With the use of dual fuel technology, the engine emissions decreased NOx, CO and PM emissions in comparison with a conventional diesel engine. Meanwhile, some type of problems related to the dual-fuel mode such as thermal efficiency relatively low during operation of the engine at the small and moderate loadings. Also, with the use of dual fuel emission of unburned hydrocarbon is increased considerably [14].

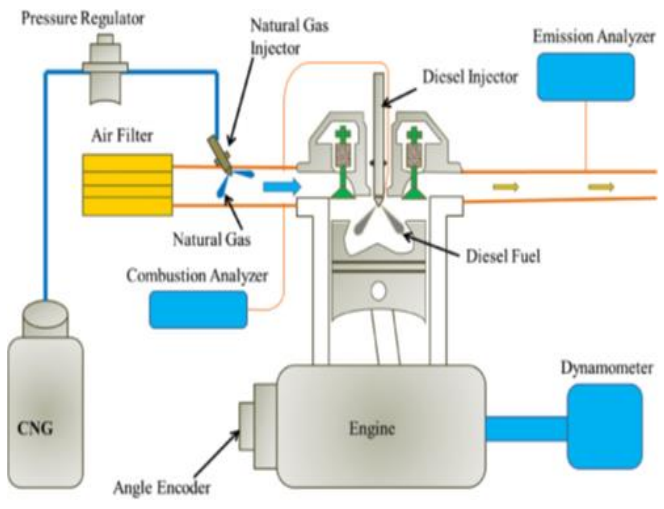

Fig. 1. The systematic diagram of dual fuel mode [15].

Fig. 1 is a schematic representation of dualfuel engine with its components highlighted in different colors.

\section{Engine Emission Characteristics}

\subsection{Nitrogen Oxides (NOx)}

In diesel engines, $\mathrm{NO}_{\mathrm{x}}$ emissions are very harmful. It consists of nitrogen dioxide $\left(\mathrm{NO}_{2}\right)$ and nitrogen monoxide (NO). There are usually two mechanisms involved in the combustion mode which results in the $\mathrm{NO}_{\mathrm{x}}$ formation namely as prompt mechanism (Fenimore mechanism) and thermal mechanism (Zeldovich mechanism).

Thermal $\mathrm{NO}_{\mathrm{X}}$ depends upon the combustion temperature and amount of oxygen. In the thermal mechanism, if the engine in-cylinder temperature is higher than the $1800 \mathrm{~K}, \mathrm{NO}_{\mathrm{x}}$ formation starts and it increases gradually with the increase of temperature [16].

In the prompt mechanism, during the fuel combustion hydrocarbon fragments especially $\mathrm{CH}_{2}$ and $\mathrm{CH}$ reacts with $\mathrm{N}_{2}$, resulting in the formation of prompt NO, which is the C-N species [17].

Thermal mechanism is accepted to be as the major contributor of $\mathrm{NO}_{\mathrm{X}}$ during normal diesel engine operating conditions [18].

\subsection{Carbon Monoxide(CO)}

$\mathrm{CO}$ is the most detrimental emissions from a diesel engine. It is formed due to the presence of unburned fuel and in-cylinder combustion temperature. $\mathrm{CO}$ is mostly produced because of oxygen shortage in the fuel rich area. Also if the in-cylinder temperature is lower than $1450 \mathrm{k}, \mathrm{CO}$ can be increased in the fuel lean area [19].

\subsection{Hydrocarbon (HC)}

$\mathrm{HC}$ is also the outcome of unburned fuel in the combustion temperature. But for the entire oxidation, the temperature of $\mathrm{HC}$ is low. With the autonomy of actual fuel form, it has been observed to be near about $1200 \mathrm{~K}$ [20].

\subsection{Carbon dioxide $\left(\mathrm{CO}_{2}\right)$}

$\mathrm{CO}_{2}$ is produced due to complete burning of fuel during the combustion process. However, the fuel is first oxidized into $\mathrm{CO}$, then due to the increase of combustion temperature and existence of oxygen concentration the fuel is further oxidized into $\mathrm{CO}_{2}$. Therefore, $\mathrm{CO}_{2}$ highly rely on in-cylinder temperature and oxygen presence. 
Ghazanfar Mehdi (et al.), An Experimental and Comparitive study about the engine emissions of conventional diesel engine and dual fuel engine

\section{Experimental Procedure}

A single cylinder four stroke engine $(8.6 \mathrm{Hp}$ LA186F) has been used. In this experiment, the engine emission effects of the diesel engine and dual-fuel engine are investigated.

Initially, diesel fuel is used for five minutes only without any load until the engine reaches to stable operating state. Later engine speed is set at $1600 \mathrm{rpm}$ through a throttle valve of the engine.

A TRICOR mass flow meter, Bronkhorst mass flow meter, and turbine mass flow meter were used for measuring the diesel fuel, natural gas, and air respectively. A portable gas analyzer (Autologic Company) was used to measure the exhaust emissions of the engine such as $\mathrm{NO}_{\mathrm{X}}$, $\mathrm{CO}, \mathrm{CO}_{2}$, and $\mathrm{HC}$.

The calibration of the gas analyzer is necessary for obtaining the accurate measurements after each measurement. Primarily, all the experiments conducted at maximum operating load, then with moderate operating loads and keeping same engine speed.

The experiment was performed on three operating engine speeds 1600,1800 and 2000rpm for efficient comparison. The engine was loaded till the maximum condition obtained for every speed. After finishing measurement on a diesel engine, it is necessary to cool engine for re-operation for accurate results.

In the dual fuel mode, initially, it is very essential to warm the engine by supplying the pilot fuel for five minutes. Then, natural gas is allowed to the cylinder, passing through the gas regulator. The pilot fuel remains unchanged throughout the experiment. But the flow of natural gas is increased only for obtaining and controlling the particular engine speeds.

\section{Results and Discussion}

\subsection{Exhaust Emission for Maximum and Moderate Load Operating Conditions}

\subsubsection{Oxides of Nitrogen $\left(\mathrm{NO}_{\mathrm{x}}\right)$}

It has been proved that in the dual fuel engine, $\mathrm{NO}_{\mathrm{x}}$ emissions are reduced in both moderate and maximum operating loading conditions in comparison with conventional diesel fuel engine. In both conventional diesel mode as well as dual fuel mode $\mathrm{NO}_{\mathrm{x}}$ emission increases with the rise of engine speed which also results in the rise of exhaust temperature. This can be represented in Fig. 2.

Natural gas possesses a high value of specific heat capacity as compared with air. Since with the use of natural gas overall heat capacity rises due to this reason mean temperature reduces close to the ending of the compression stroke and throughout the whole combustion practice.

The $\mathrm{NO}_{\mathrm{X}}$ formation is directly associated with the increase of engine in-cylinder temperature. However, the result is more efficient because at lower engine load combustion temperature is always reduced as the quantity of air and oxygen concentration lessen by means of natural gas. When the speed of the engine increases there is lesser time for the formation of $\mathrm{NO}_{\mathrm{x}}$ because of which the emission of $\mathrm{NO}_{\mathrm{X}}$ decreases.

In dual fuel engine, ignition delay occurs because of the poor burning of natural gas. Due to this in-cylinder temperature decreases which result in a reduction of $\mathrm{NO}_{\mathrm{x}}$ emission.

According to the dual fuel mode, $\mathrm{NO}_{\mathrm{x}}$ emissions are reduced up to an average of $73 \%$ at maximum operating conditions and $72 \%$ at moderate operating conditions. Consequently, overall $\mathrm{NO}_{\mathrm{x}}$ reduction throughout the experiment is $72.5 \%$ that can be clearly seen in Fig 2 . 


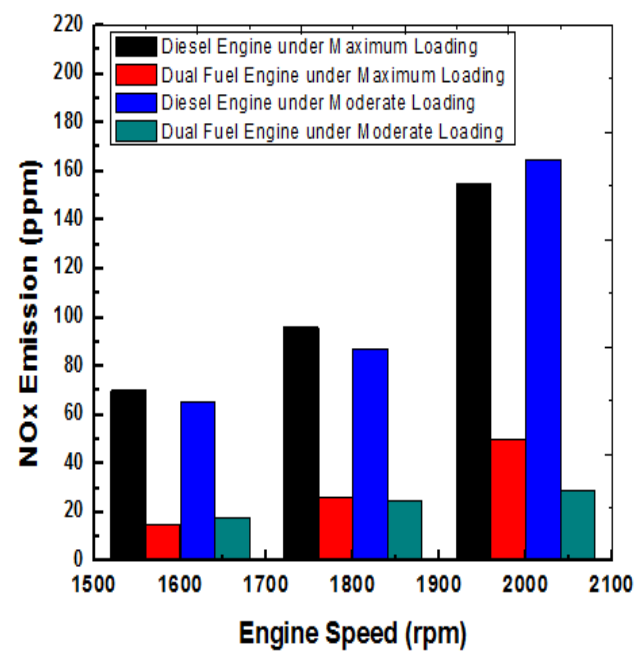

Fig. 2. Exhaust NOx Emission for Maximum and Moderate Loading with different engine speeds.

\subsubsection{Carbon Dioxide}

It has been found that in the dual fuel mode, $\mathrm{CO}_{2}$ emissions are reduced for both moderate and maximum operating loading conditions as compared with conventional diesel fuel engine as seen in Fig. 3.

In dual fuel mode, $\mathrm{CO}_{2}$ emissions are lower because natural gas is low carbon content as compared with the diesel fuel. In dual fuel process, there is a problem of poor combustion because little amount of the fuel is not completely oxidized to $\mathrm{CO}$ and flow out from the exhaust valve, which leads to the decrease of $\mathrm{CO}_{2}$ emission.

With the increase of engine speed, the amount of $\mathrm{CO}_{2}$ emission also increases because the engine required more fuel. Therefore the number of carbon contents increases in the combustion chamber. Due to the larger carbon content chains in the diesel fuel, the range of $\mathrm{CO}_{2}$ is higher at all speeds of engine.

According to the dual fuel mode, $\mathrm{CO}_{2}$ emissions are reduced up to an average of $37 \%$ at maximum operating conditions and $32 \%$ at moderate operating conditions. Consequently,

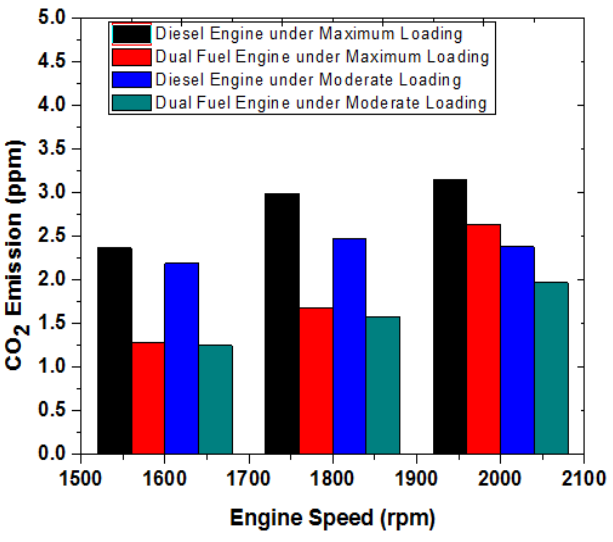

Fig. 3. Exhaust $\mathrm{CO}_{2}$ Emission for Maximum and Moderate Loading with different engine speeds

overall $\mathrm{CO}_{2}$ reduction throughout the experiment is $34.5 \%$ that can be clearly seen in Fig. 3 .

\subsubsection{Carbon Monoxide}

It has been proved that in the dual fuel mode the $\mathrm{CO}$ emissions are reduced in both moderate and maximum operating loading conditions in comparison with conventional diesel fuel engine as shown in Fig.4. However, if the engine is running at lower speed, $\mathrm{CO}$ reduction is more noticeable.

$\mathrm{CO}$ is produced because of the incomplete fuel combustion, engine coldness and lacking of air concentration in the cylinder. With the decrease of air to fuel ratio, the amount of $\mathrm{CO}$ increases, if the mixture is rich with fuel.

In dual fuel mode, emissions of carbon monoxide decreased as compared with normal diesel engine with varying engine speeds. Due to the better combustion efficiency of natural gas produces less amount of $\mathrm{CO}$, because natural gas is a gaseous fuel generally contains little quantity of contaminants than diesel fuel. 


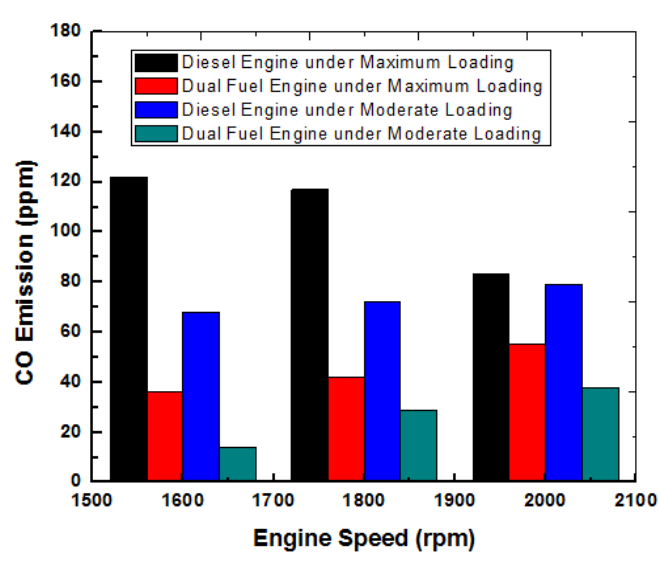

Fig. 4. Exhaust CO Emission for Maximum and Moderate Loading with different engine speeds.

With the increase of engine speeds, $\mathrm{CO}$ emission increased in dual fuel method. However, when engine speed increases the dwelling time of fuel inside the cylinder shorten, resulting in superior $\mathrm{CO}$ formation.

According to the dual fuel mode, $\mathrm{CO}$ emissions are reduced up to an average of $56 \%$ at maximum operating conditions and $63.66 \%$ at moderate operating conditions. Consequently, overall $\mathrm{CO}$ reduction throughout the experiment is 59.8\% that can be clearly seen in Fig.4.

\subsubsection{Hydrocarbons}

It has been observed in the dual fuel mode the amount of $\mathrm{HC}$ emissions are much more increased in both moderate and maximum operating loading conditions in comparison with normal diesel engine as shown in Fig.5.

However, the $\mathrm{HC}$ increased several times in comparison with normal diesel combustion. This is due to the incomplete combustion and remains of unburned fuel in the combustion chamber.

In dual fuel mode, it shows trade-off connection in between $\mathrm{HC}$ and $\mathrm{NO}_{\mathrm{X}}$ emission, due to less air to fuel ratio oxygen concentration is not enough for combustion process.

The level of $\mathrm{HC}$ emissions are reduced when load increases, resulting in better efficiency for the combustion. Due to this, it is observed that
$\mathrm{HC}$ emission level is lower during maximum loading conditions. It has been found that in dual fuel method $\mathrm{HC}$ reduced when the engine speed is increased since the combustion process is better when the engine operates at high speeds.

Due to the scavenging process during the valve opening time, a small amount of air and natural gas mixture directly passed through the exhaust valve, which results the increase of HC.

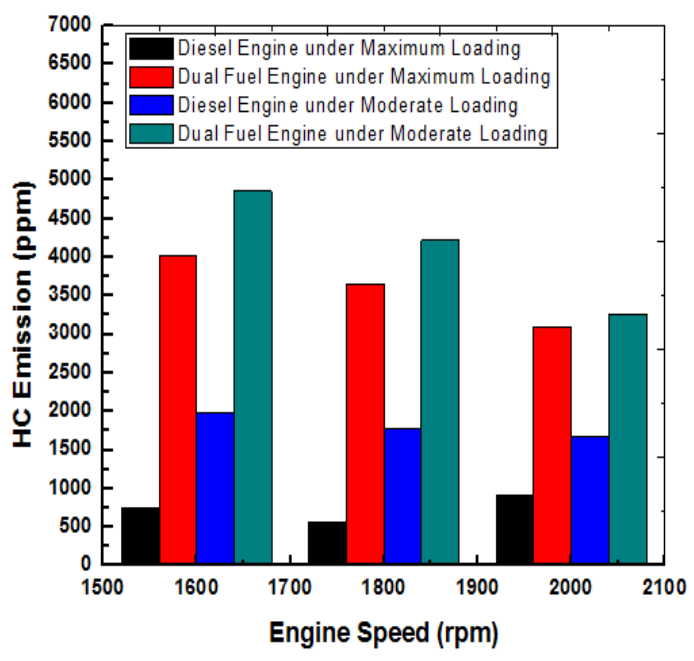

Fig. 5. Exhaust HC Emission for Maximum and Moderate Loading with different engine speeds.

According to the dual fuel mode, HC emissions are increased up to an average of $78.5 \%$ at maximum operating conditions and $55 \%$ at moderate operating conditions. Consequently, overall $\mathrm{HC}$ increment throughout the experiment is $66.76 \%$ that can be clearly seen in Fig.5.

\section{Conclusion}

In this study, it has been established that a significant reduction takes place in $\mathrm{NO}_{\mathrm{X}}, \mathrm{CO}_{2}$ and $\mathrm{CO}$ emissions with the use dual fuel mode in comparison with the normal diesel engine. However, $\mathrm{HC}$ emission is increased several times in comparison with diesel fuel engine. In dual fuel mode, it shows the trade-off link in between $\mathrm{HC}$ and $\mathrm{NO}_{\mathrm{x}}$ emission. Therefore our investigation concludes that dual fuel engine is 
more environmental friendly in contrast with diesel engine.

\section{REFERENCES}

[1] Pan HS, Pournazeri S, Princevac M, et al. Effect of hydrogen addition on criteria and greenhouse gas emissions for a marine diesel engine. Int $\mathbf{J}$ Hydrog Energy;39:11336-45, 2014.

[2] W. Tutak, K. Lukács, S. Szwaja, Á. Bereczky, Alcohol-diesel fuel combustion in the compression ignition engine, Fuel. 154,196-206. 2015.

[3] L. Stayner, D. Dankovic, R. Smith, K. Steenland, Predicted lung cancer risk among miners exposed to diesel exhaust particles,Am. J. Ind.Med. 34 (3) 207-219. 1998).

[4] J.D. McDonald, M.D. Reed, M.J. Campen, E.G. Barrett, J. Seagrave, J.L. Mauderly.

[5] A. Demirbas, Methane gas Hydrate: Springer Science \& Business Media, 2010.

[6] Korakianitis T, Namasivayam AM, Crookes RJ. Natural-gas fueled spark ignition (SI) and compression-ignition (CI) engine performance and emissions. Prog Energy Combust Sci;37(1):89-112. 2011.

[7] Jin K, Takashi O, Yasuhiro D, Ryouji K, Takeshi S. Combustion and exhaust gas emission characteristics of a diesel engine dual fueled with natural gas. JSAE Rev;21(4):489-96,2000.

[8] A. Demirbas, Methane gas Hydrate: Springer Science \& Business Media, 2010.

[9] Q.C. Zhang, G.S. Chen, Z.Q. Zheng, H.F Liu, J. Xu, M.F. Yao, Combustion and emissions of 2,5-dimethylfuran addition on a diesel engine with low temperature combustion, Fuel 103 730-735. 2013.

[10] B.B. Yang, M.F. Yao, W.K. Cheng, Z.Q. Zheng, L. Yue, Regulated and unregulated emissions froma compression ignition engine under low temperature combustion fuelled with gasoline and n-butanol/gasoline blends, Fuel $120,163-170.2014$.

[11] O.M.I. Nwafor, Effect of choice of pilot fuel on the performance of natural gas in diesel engines, Renew. Energy 21 (34),495-504. 2000.
[12] A. Paul, R.S. Panua, D. Debroy, P.K. Bose, Effect of compressed natural gas dual fuel operation with diesel and Pongamia pinnata methyl ester (PPME) as pilot fuels on performance and emission characteristics of a CI (compression ignition) engine, Energy $68,495-509,2014$.

[13] R.G. Papagiannakis, D.T. Hountalas, C.D. Rakopoulos, Theoretical study of the effects of pilot fuel quantity and its injection timing on the performance and emissions of a dual fuel diesel engine, Energy Convers. Manag. 48 (11) 2951-2961, 2007.

[14] Liu H, Wang Z, Long Y, Xiang SZ, Wang JX, Scott, Wagnon W. Methanol-gasoline Dual-fuel Spark Ignition (DFSI) combustion with dual-injection for engine particle number (PN) reduction and fuel economy improvement. Energy;89:1010-7, 2015.

[15] Wang-Helmreich H, Lochner S. The potential of natural gas as a bridging technology in low-emission road transportation in Germany. Therm Sci;16(3)729-46, 2012.

[16] J.B. Heywood, Internal Combustion Engine Fundamentals: Mcgraw-Hill New York, 1988.

[17] S.K. Hoekman, C. Robbins, Review of the effects of biodiesel on NOx emissions, Fuel Process. Technol. 96, 237-249, 2012.

[18] C.T. Bowman, Kinetics of pollutant formation and destruction in combustion, in: N.A. Chigier (Ed.), Energy and Combustion Science (Student Edition One).,33-45 (Pergamon1979).

[19] T. Kitamura, J. Senda, H. Fujimoto, Mechanism of smokeless diesel combustion with oxygenated fuels based on the dependence of the equivalence ratio and temperature on soot particle formation, Int. J. Eng. Res. 3 (4) 223-248. 2002.

[20] J. Liu, F. Yang, H.W. Wang, M.G. Ouyang, S.G. Hao, Effects of pilot fuel quantity on the emissions characteristics of a $\mathrm{CNG}$ /diesel dual fuel engine with optimized pilot injection timing, Appl. Energy 110,201-206, 2013. 